Many conservationists argue that invasive species form one of the most important threats to ecosystems the world over, often spreading quickly through their new environments and jeopardising the conservation of native species. As such, it is important that reliable predictions can be made regarding the effects of new species on particular habitats and ecosystems.

This book provides a critical appraisal of ecological theory using case studies of biological invasions in Australasia. Each chapter is built around a set of 11 central hypotheses from community ecology, which were mainly developed in North American or European contexts. The authors examine the hypotheses in the light of evidence from their particular species, testing their power in explaining the success or failure of invasion, and accepting or rejecting each hypothesis as appropriate. The conclusions have far-reaching consequences for the utility of community ecology, suggesting a rejection of its predictive powers and a positive reappraisal of natural history.

'The editors have brought together 34 scientists with solid field experience to write 18 chapters on specific examples of invasions ... The results are spectacularly interesting for those of us who are interested in natural history, but they also provide a strong warning for ecologists who think time's arrow always points in the direction of theoretical progress and more precise generalisation.

From the foreword by Charles I. Krebs

This book represents a novel and exciting approach to testing some fundamental ecological ideas such as the niche concept, competition, disturbance, and life history strategy. It does so using invasive alien species, with Australia as both the invaded environment, as well as the source of the invasives. The principal intent of this book is to inform the science of ecology, but it is rich in insights of value to those grappling with the management of this great threat to global biodiversity.

Mark Lonsdale, CSIRO
Herbert H. T. Prins is Professor of Resource Ecology at Wageningen University. He was twice visiting professor with CSIRO and a Foundation Fellow of the Royal Melbourne Institute of Technology.

lain 1. Gordon is Chief Executive and Director of the James Hutton Institute. He worked for CSIRO for 7 years, managing major research portfolios on land management to protect the Great Barrier Reef and conserving Australia's biodiversity.

Cover illustration: the camel is a prime example of an invasive species, here photographed in typical, still undisturbed native Australian deser hummock grassland. In 1860 the camel was introduced into the Australian outback as a beast of burden from what is now Pakistan. Today there are over 1 million feral camels ranging over more than 3 million $\mathrm{km}^{2}$, with the population doubling every 8 years. Image courtesy of Northern Territory Government, Australia.

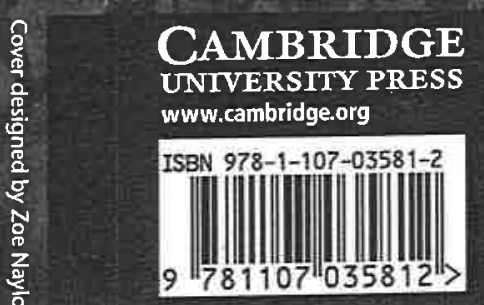

옥.

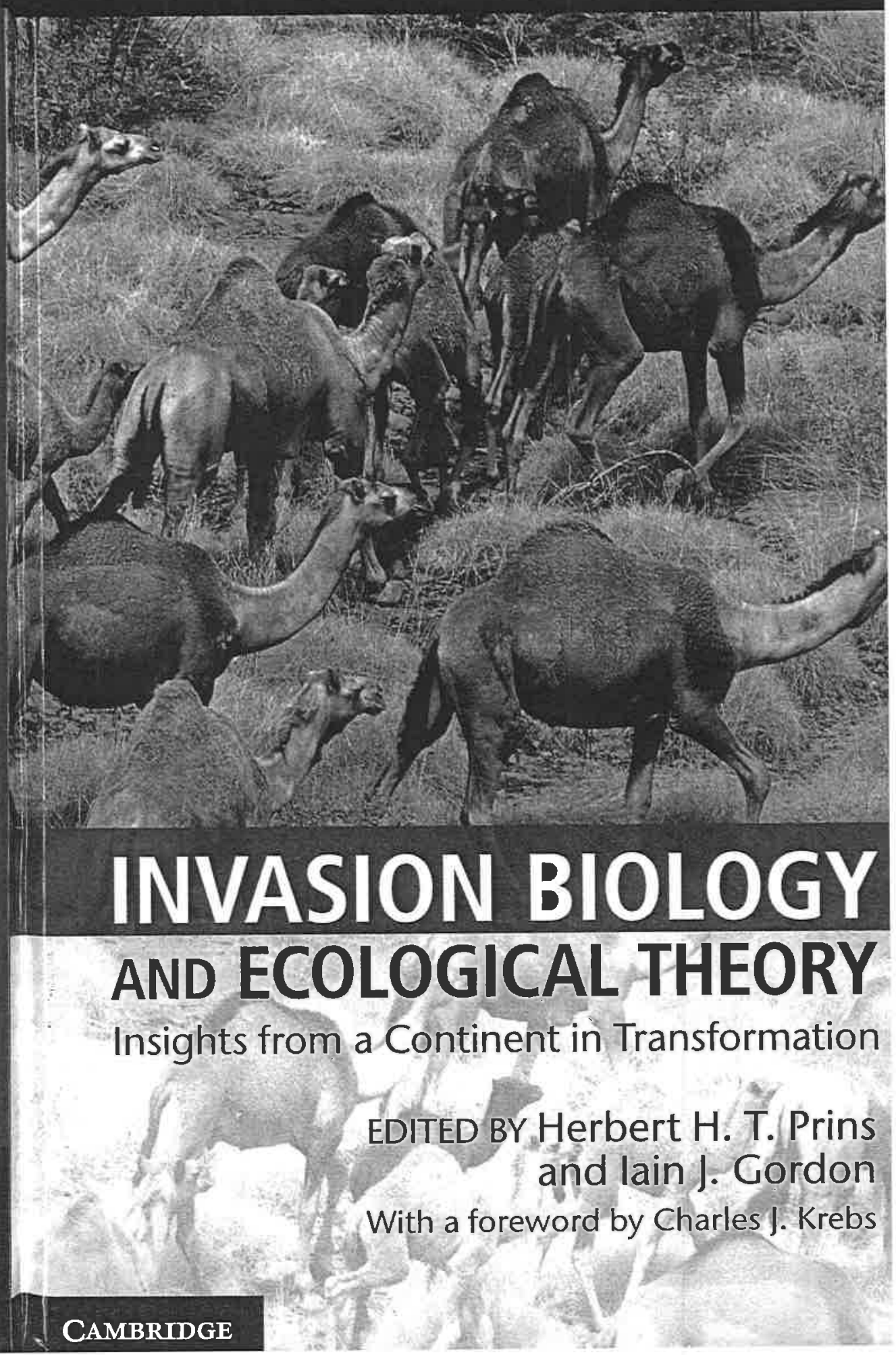




\section{Invasion Biology and Ecological}

Theory

Insights from a Continent in Transformation

EDITED BY

HERBERT H. T. PRINS

Wageningen University, The Netherlands

AND

IAIN J. GORDON

James Hution Institute, UK 


\section{CAMBRIDGE \\ UNIVERSTTY PRESS}

University Printing House, Cambridge CB2 8BS, United Kingdom

Published in the United States of America by Cambridge University Press, New York

Cambridge University Press is part of the University of Cambridge.

It furthers the University's mission by disseminating knowledge in the pursuit of duction, leaning,

www.cambridge.org

Ther

(c) Cambridge University Press 2014

This publication is in copyright. Subject to statutory exception

and to the provisions of relevant collective licensing agreements,

no to the provis

permission of Cambridge University Press.

First published 2014

Printed and bound in the United Kingdom by CPI Group Ltd, Croydon CR0 4YY

A catalogue record for this publication is available from the British Library

ISBN 978-1-107-03581-2 Hardback

Cambridge University Press has no responsibility for the persistence or accuracy of URLs for external or third-party internet websites referred to in this publication

and does not guarantee that any content on such websites is, or will remain,

accurate or appropriate.

\section{Contents}

List of contributors

page vii

Foreword

Charles J. Krebs

1 Testing hypotheses about biological invasions and Charles

Darwin's two-creators rumination

Herbert H. T. Prins and lain J. Gordon

Part I Ancient invaders

Australia's Acacia unrecognised convergent evolution Joseph T. Miller and Martin Burd

The mixed success of Mimosoideae clades invading into Australia Kyle W. Tomlinson

4 Perspectives from parrots on biological invasions Leo Joseph

$5 \quad$ Invasion ecology of honeyeaters Janette A. Nomman and Leslie Christidis

6 The invasion of terrestrial fauna into marine habitat: blrds in mangroves David Luther

7 The biological invasion of Sirenia into Australasia

Hans H. de longh and Daryl P. Domning

$8 \quad$ Flying foxes and drifting continents

David A. Westcott and Adam McKeown

$9 \quad$ Invasion ecology of Australasian marsupials

Christopher R. Dickman

Murine rodents: late but highly successful invaders

Ken Aplin and Fred Ford 
The development of a climate: an arid continent with wet fringes Sandra McLaren, Malcolm W. Wallace, Stephen $\downarrow$. Gallagher, Barbara E. Wagstaff and Anne-Marie P. Tosolini

Part II Modern invaders

Invasion by woody shrubs and trees

Kis French, Ben Gooden and Tanya Mason

Modem tree colonisers from Australia into the rest of the world Trevor H. Booth

Failed introductions: finches from outside Australia

Jan Komdeur and Martijn Hammers

16 The skylark

Judit K. Szabo

Why northern hemisphere waders did not colonise the south Ken Kraajeveld

18 Weak migratory interchange by birds between Australia and Asia David Roshier and Leo Joseph

19 Introducing a new top predator, the dingo

Chrictopher N. Johnson and Mike Letnic

The European rabbit: Australia's worst mammalian invade Steven R. McLeod and Glen Saunders

The rise and fall of the Asian water buffalo in the monsoona tropics of northem Australia Patricia A. Werner

A critique of ecological theory and a salute to natural history Herbert H. T. Prins and lain J. Gordon

Index

\section{Contributors}

\section{Ken Aplin}

Division of Mammals

United States National Museum

Smithsonian Institution

Washington DC

USA

Trevor H. Booth

CSIRO Ecosystem Sciences and Climate Adaptation Flagship

Canberra ACT

Australia

\section{Martin Burd}

School of Biological Sciences

Monash University

Melbourne, VIC

Australia

\section{Leslie Christidis}

National Marine Science Centre

Southem Cross University

Coffs Harbour, NSW

Australia

Christopher R. Dickman

The Institute of Wildlife Research

School of Biological Sciences

University of Sydney

Sydney, NSW

Australia

\section{Daryl P. Domning}

Department of Anatomy

Howard University College of Medicine

Washington DC

USA 
Fred Ford

CSIRO Australian National Wildlife Collection

Canberra, ACT

Australia

\section{Kris French}

Institute for Conservation Biology and Environmental Management

School of Biological Sciences

University of Wollongong

Wollongong, NSW

Australia

\section{Stephen J. Gallagher}

School of Earth Sciences

University of Melbourne

Victoria

Australia

\section{Ben Gooden}

Institute for Conservation Biology and Environmental Management

School of Biological Sciences

University of Wollongong

Wollongong, NSW

Australia

\section{lain J. Gordon}

James Hutton Institute

Invergowrie

Dundee

UK

\section{Martijn Hammers}

Behavioural Ecology and Self-Organisation

Centre for Ecological and Evolutionary Studies

University of Groningen

Groningen

\section{The Netherlands}

\section{Hans H. de longh}

Institute of Environmental Sciences

Department of Conservation Biology

Leiden University

\section{Leiden}

The Netherlands

Christopher N. Johnson

School of Zoology

University of Tasmania

\section{Australia}

Leo Joseph

Australian National Wildlife Collection

CSIRO Ecosystem Sciences

Canberra, ACT

Australia

\section{Jan Komdeur}

Behavioural Ecology and Self-Organisation

Centre for Ecological and Evolutionary Studies

University of Groningen

Groningen

The Netherlands

\section{Ken Kraaijeveld}

Bioinformatics

University of Applied Sciences Leiden

Leiden

\section{The Netherlands}

\section{Mike Letnic}

Australian Wetlands, Rivers and Landscapes Centre and

School of Biological, Earth and Environmental Sciences

University of New South Wales

Sydney, NSW

Australia

\section{David Luther}

Biology Department

George Mason University

Fairfax, VA

USA

\section{Tanya Mason}

Institute for Conservation Biology and Environmental Management

School of Biological Sciences

University of Wollongong

Wollongong, NSW

\section{Australia}

Adam Mckeown

CSIRO Ecosystem Sciences

Atherton, QLD

Australia 


\section{Sandra McLaren}

School of Earth Sciences

University of Melboume

Victoria

Australia

\section{Steven R. McLeod}

NSW Department of Primary Industries

Vertebrate Pest Research Unit

Orange Agricultural Institute

Orange, NSW

Australia

\section{Joseph T. Miller}

Centre for Australian National Biodiversity Research

CSIRO Plant Industry

Canberra, ACT

Australia

\section{Janette A. Norman}

University of Melbourne

Melboume, VIC

Australia

Herbert H. T. Prins

Resource Ecology Group

Wageningen University

Wageningen

The Netheriands

\section{David Roshier}

Australian Wildlife Conservancy

Adelaide, SA

Australia

\section{Glen Saunders}

NSW Department of Primary Industries

Vertebrate Pest Research Unit

Orange Agricultural Institute

Orange, NSW

Australia

\section{Carol Ann Stannard}

James Hutton Institute

Craigiebuckler

Aberdeen

\section{Judit K. Szabo}

Research Institute for the Environment and Livelihoods

Charles Darwin University

Darwin, NT

Australia

\section{Kyle W. Tomlinson}

Resource Ecology Group

Wageningen University

Wageningen

The Netherlands

\section{Anne-Marie P. Tosolini}

School of Earth Sciences

University of Melbourne

Victoria

Australia

\section{Barbara E. Wagstaff}

School of Earth Sciences

University of Melbourne

Victoria

Australia

Malcolm W. Wallace

School of Earth Sciences

University of Melbourne

Victoria

Australia

\section{Patricia A. Werner}

Fenner School of Environment and Society

Australian National University

Canberra ACT

Australia

\section{David A. Westcott}

CSIRO Ecosystem Sciences

Atherton, QLD

Australia 


\section{The development of a climate: an arid continent with wet fringes}

Sandra McLaren, Malcolm W. Wallace, Stephen J. Gallagher, Barbara E. Wagstaff and Anne-Marie P. Tosolini

\section{Introduction}

The Australian continent is large and therefore exhibits a range of very different climatic zones. Broadly, the continent is characterised by arid climatic regimes: four-fifths of the landmass receiving an annual rainfall of less than $600 \mathrm{~mm}$ (Figure 12.1) and one-half of the continent receiving less than $300 \mathrm{~mm}$. These arid and semi-arid regions form the greatest proportion of inland Australia, and are fringed by narrow, wet and temperate climatic zones along the southwestern, southem and eastern coastal zones (Figure 12.1). Tropical monsoonal rainfall characterises the northern coastal zones. Compared to other continents on Earth, Australia has by far the lowest average rainfall. This low precipitation rate is coupled with a high evaporation rate meaning that surface water availability is also anomalously low compared to global averages. Average annual temperature also shows significant variation (Figure 12.1) and in most areas there is also a high diumal variation in temperature.

It is well known, however, that the currently arid areas of inland Australia were significantly wetter in the geological past, from the early Cenozoic (a period of geological time from c. 65 Ma until the present day; Gradstein et al. 2004) until at least the early Miocene (c. 23 Ma) (e.g. Kershaw et al. 1994; Martin 2006). Much of our current knowledge of climate change from the early Cenozoic to the present is deduced from observed variations in the isotopic signature of marine sediments (e.g. deMenocal 1995; Lisiecki and Raymo 2005; Raymo et al. 2006) as well as the distribution, chemistry and palynological assemblages of terrestrial and marine sediments and sedimentary rocks.

Globally, the impact of climatic shifts throughout the geological record has been profound. Numerous examples of changes in species development and/or distribution have been documented in the Cenozoic (e.g. Vizcaino et al. 2004; Edwards et al. 2007; Meloro et al. 2008; Palombo et al. 2009) and the step-wise aridification of Africa, for example, is thought to have played an important role in forcing the evolution of hominids (e.g. Stanley 1992 Reed 1997; Bobe and Behrensmeyer 2004; Wynn 2004). Notwithstanding the significance of climate change in this interval, the timing of onset of arid climatic regimes in Australia remains poorly constrained and the factors controlling changes in climatic dynamics are still debated (e.g. Cane and Molnar 2001). This chapter summarises the key characteristics of the modern Australian climate and presents a review of our understanding of the timing of the

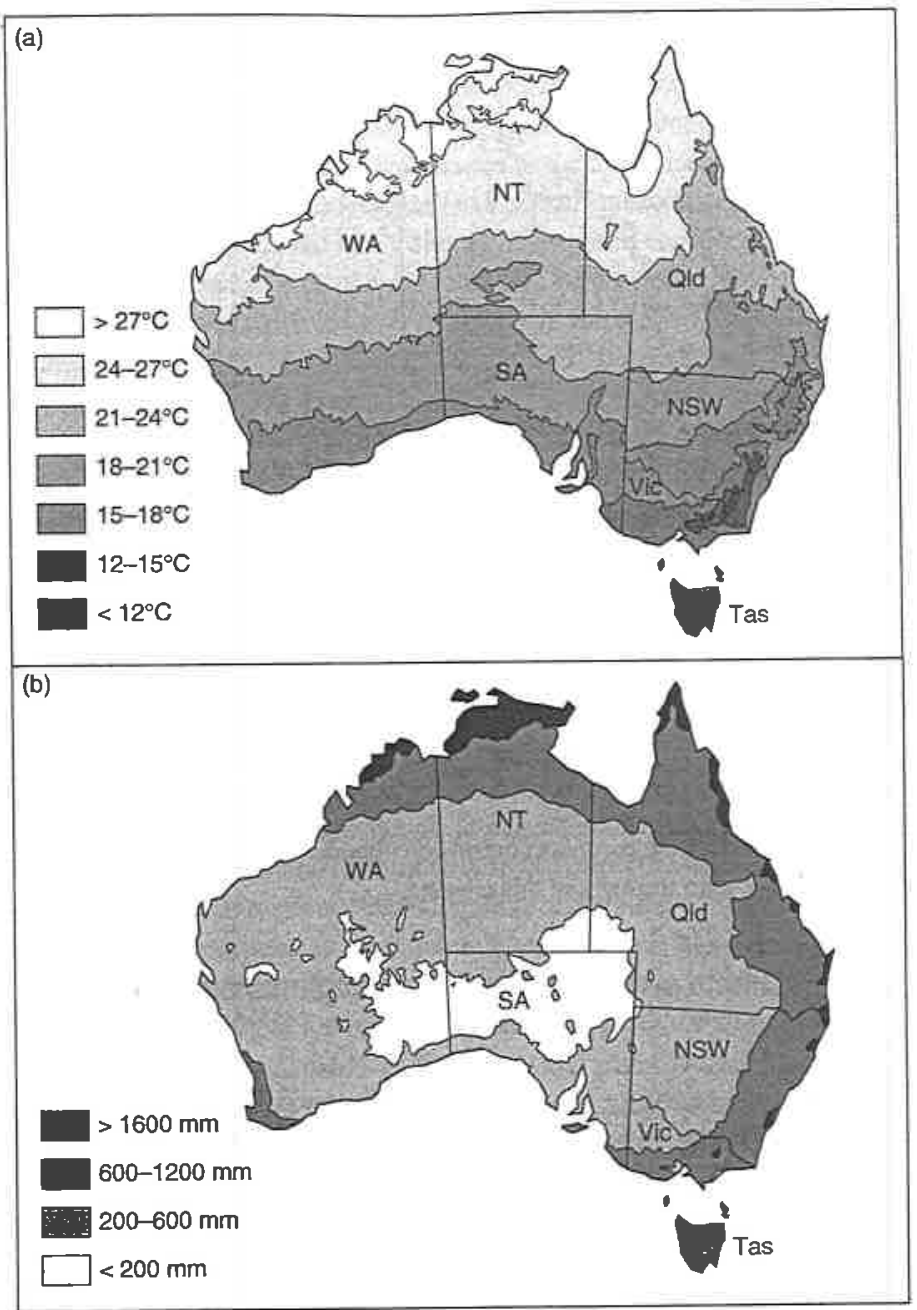

Figure 12.1

Climatic features of the modern Australian continent (a) mean annual temperature and (b) mean annual rainfall. Figures modified from the Australian Bureau of Meteorology and reproduced with permission. WA $=$ Western Australia, $\mathrm{NT}=$ Northern Territory, Q1d $=$ Queensland, SA $=$ South Australia, NSW $=$ New South Wales, Vic $=$ Victoria, Tas $=$ Tasmania.

development of this climatic zonation and its origins. We focus particularly on the development of the continent's dominant arid climatic regime. Currently available data suggest that the onset of arid climatic conditions was gradual and step-wise and occurred significantly earlier in southeastem Australia than previously thought It also seems likely that the onset of aridity was diachronous across the continent, beginning earlier in western and central 


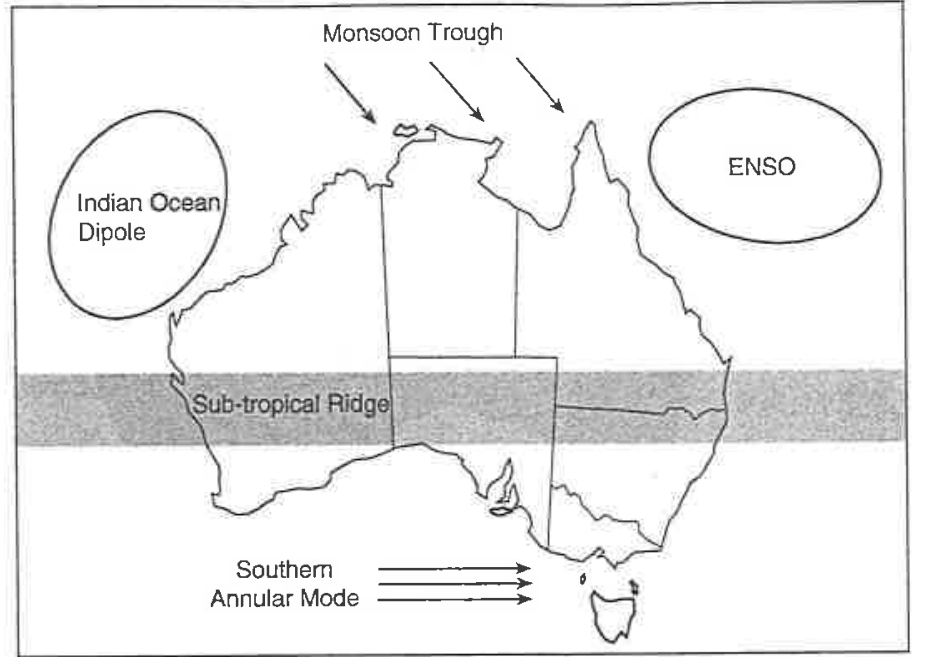

Figure 12.2 Key drivers of the modern climate in the Australian region. Figure modified from the Australian Bureau of Meteorology and reproduced with permission.

Australia, reflecting the complex controls on climate. The geological timescale of Gradstein et al. (2004) is used throughout this chapter.

\section{Modern climate system: Australia in a regional context}

The modern-day climatic zonation within Australia broadly reflects the effect of atmospheric and oceanic circulation patterns and thus the latitudinal position of the continent. Climate scientists recognise a number of key climate drivers in the region (Figure 12.2) including: (1) the Indian Ocean Dipole (IOD), which describes a key part of the influence of Indian Ocean sea-surface temperatures over the Australian climate system and which influences the variability of rainfall in all areas of the continent (e.g. Behera and Yamagata, 2001); (2) El Niño/La Niña Southem Oscillation (ENSO), the shift in weather patterns across the Pacific Ocean due to changing sea-surface temperatures, which affects rainfall predominantly in eastern Australia (e.g. McBride and Nicholls, 1983; Allan et al., 1996); (3) the Southern Annular Mode (SAM), related to the north-south movement of westerly winds in mid-high latitudes and which influences rainfall in southem Australia (e.g. Gillett et al., 2006); and (4) the subtropical ridge (STR), a belt of high pressure in the middle latitudes which impacts on climate seasonality across Australia and the southward extension of the monsoon trough (e.g. Kidson 1988; Williams and Stone 2009). Seasonality, rainfall patterns as well as average maximum temperatures at any location in Australia or the region are the product of a complex interplay of these climate drivers.
In the northern Australian coastal fringes annual rainfall averages $1500-3200 \mathrm{~mm}$ (Figure 12.1) and is highly seasonal with significant falls associated with tropical monsoon activity in the summer. Mean annual temperatures are in the range $25-28^{\circ} \mathrm{C}$ (Australian Bureau of Meteorology, Figure 12.1). This tropical and humid subtropical climate is broadly similar to that of neighbouring landmasses to the north, including the Indonesian archipelago and New Guinea. These regions have typical equatorial climates characterised by high average annual rainfall and small diumal temperature variations. In contrast, climate conditions in southeastern Australia are temperate with average annual rainfall in the range of $600-2000 \mathrm{~mm}$ and mean daily temperatures in the range $12-18^{\circ} \mathrm{C}$ (Australian Bureau of Meteorology, Figure 12.1). Tasmania, south of the Australian continental landmass, is characterised by average rainfall of $500-3200 \mathrm{~mm}$ and average temperatures of $9-12^{\circ} \mathrm{C}$ (Australian Bureau of Meteorology, Figure 12.1). This climate most closely resembles the maritime climate of Australia's nearest easterly neighbour, New Zealand.

Over four-fifths of the continent, and almost all of the continental interior, is characterised by arid climatic regimes with average annual rainfall in the range $0-400 \mathrm{~mm}$ and average daily temperatures between $19-25^{\circ} \mathrm{C}$ (Australian Bureau of Meteorology, Figure 12.1). These arid regions are classic subtropical deserts and are situated beneath the downward circulation of the southern hemisphere Hadley Cell (Hesse et al. 2004) Such widespread arid conditions are least like those found in neighbouring landmasses and are a key point of difference between the Australian continent and its neighbours.

The variability of modern climate (rainfall and temperature) across the continent is reflected in the type and distribution of vegetation. Martin (2006) presents a summary of the key moden vegetation types as described by Specht and Specht (2002). These include: (1) closed-forest or rainforest including tropical, subtropical and temperate species, which are generally restricted to high rainfall regions and which generally lack significant Eucalyptus; (2) sclerophyll forest, dominated by Eucalyptus and/or Casuarina, which can be either wet (with a rainforest understorey) or dry (with a sclerophyll understorey); (3) open vegetation, particularly shrublands and grasslands; (4) arid and semi-arid vegetation dominated by Acacia shrublands and low woodlands and which generally lack significant Eucalyptus; and (5) chenopod shrublands dominated by annual and perennial species. Broadly, Australia is dominated by flora that is well adapted to the widespread arid and semi-arid climatic conditions. In these regions, Acacia, Casuarina, chenopods and grasses are dominant (Groves 1999) and Eucalyptus is less dominant. Other vegetation types, particularly tropical and temperate rainforest, are restricted to specific climatic niches characterised by particular humidity, rainfall and/or temperature conditions. The strong relationship between vegetation type and climate means that spore-pollen preserved in sedimentary rocks is one of the best indicators of the nature of past climates.

\section{Climatic history of a continent}

Beyond the period of historical meteorological records, our understanding of climatic change is derived largely from the geological record. In particular, sedimentary rocks those deposited at or near the Earth's surface - can preserve an extraordinarily detailed 
history of climatic evolution. A number of observations from the rock record inform our understanding of palaeoclimatic conditions: (1) marine macrofossil and microfossil assemblages (e.g. Moss and McGowran 2003); (2) floral assemblages, as indicated by preserved spore-pollen and/or the assemblage of plant macrofossils in both terrestrial and marine sediments (e.g. Kershaw et al. 1991; McPhail 1997); (3) the isotopic composition of microfossils in sediment, particularly marine sediment (Lisiecki and Raymo, 2005); (4) the mineralogy of sedimentary rocks, including variations in the assemblage of clay minerals and the presence of evaporitic minerals (e.g. Zheng et al. 1998); and (5) palaeoecological studies of fossil mammalian assemblages (e.g. Archer 1989; Travouillon et al. 2009). Rocks that make up the Australian continent span the earliest periods of Earth history through until the present day and record evidence of some of the Earth's most dramatic climatic shifts, such as the apparently dramatic global glaciations of the Neoproterozoic 'Snowball Earth' (e.g. Hoffman et al. 1998). The highest resolution record, however, is that of the Cenozoic, where near-continuous sequences of sedimentary rocks in a variety of sedimentary basins across the continent preserve evidence for changing climatic conditions.

Competing controls have impacted on Australia's climatic regime in the geological past. As outlined in Chapter 11, following the break-up of the Gondwana supercontinent beginning in the early Cretaceous, Australia's near-constant northward tectonic motion has meant the continent has traversed a range of latitudes. Plate velocities averaging between $5 \mathrm{~cm}$ and $7 \mathrm{~cm}$ per annum have meant that any individual geographic area within Australia has moved around $7000-8000 \mathrm{~km}$ in the last $120 \mathrm{Ma}$ Another consequence of Gondwana break-up was the breaching of the Tasman Gateway between Antarctica and Tasmania (Stickley et al. 2004) and the establishment of a strong Antarctic Circumpolar current from 33 to $30 \mathrm{Ma}$ (Lyle et al. 2008). Development of this oceanic current was associated with the build-up of an extensive polar icecap that in tum steepened latitudinal temperature gradients and influenced atmospheric circulation (Macphail et al. 1994). Superposed on climatic changes driven by this latitudinal drift has been the global record of sea-level variation (Miller et al. 2005). Changes in global sea level affect the area of shallow sea and impact on total evaporation and precipitation. Global sea-level changes also affect the nature of oceanic stratification and impact on oceanic and atmospheric circulation patterns. Tectonic activity - particularly plate collision - to the north of the Australian continen has also impacted the climatic system by affecting changes in oceanic and atmospheric circulation (e.g. Gallagher et al. 2009). Tectonic activity elsewhere on the Earth may have also influenced atmospheric $\mathrm{CO}_{2}$ concentrations and therefore climate drivers (e.g. Barron and Peterson 1991).

In this section we summarise the known variation in climatic conditions from the time of break-up of Australia and Antarctica in the late Mesozoic, to the late Pleistocene. In this interval, a trend to arid climatic regimes from significantly wetter conditions is well documented (e.g. Kemp 1978; Hill 1994; Kershaw et al. 1994; Martin 2006). Here we review previously published work by summarising the climate history of the broad geographic regions of the continent.

\section{Late Mesozoic}

Prior to the break-up of Gondwana, Australia was characterised by a broadly warm climatic mode (Frakes et al. 1992). Globally, sea level was higher compared to today $(100 \pm 50 \mathrm{~m}$; Miller et al. 2005) before a significant sea-level drop at the end of the Cretaceous initiated more seasonal climatic conditions (Hays and Pitman 1973). Average global surface temperatures for the Cretaceous were $6^{\circ} \mathrm{C}$ higher than today resulting in a climate interpreted by many to have been warm, equable and lacking variability (Barron 1983). In general, Cretaceous climates are marked by a warming event around $140 \mathrm{Ma}$ which was followed by increasing climate instability from around $130 \mathrm{Ma}$. This trend culminated in a late Aptian cooling episode (Weissert and Erba 2004) around $110 \mathrm{Ma}$. Steady warming occurred from this time until around $80 \mathrm{Ma}$ after which time there was another major cooling phase until the Maastrichtian around $67 \mathrm{Ma}$ (Douglas and Savin 1975; Huber et al. 1995; Huber 1998; Clarke and Jenkyns 1999; MacLeod et al. 2001). Although the Cretaceous climate in Australia broadly follows global trends, the position of the continent at high palaeolatitudes prior to separation from Antarctica resulted in climate extremes, particularly in the south. In the Early Cretaceous lines of latitude increased from the northwest to the southeast across the continent whereas by the Late Cretaceous they increased from north to south ( $\mathrm{Li}$ and Powell 2001). This shift was due to the change in position of the palaeo south pole. However, throughout the Cretaceous the south of the continent was at least at $65^{\circ} \mathrm{S}(\mathrm{Li}$ and Powell 2001; Chapter 11 of this volume) and a variation in climate regimes occurred across the continent due to a latitudinal spread of approximately $30^{\circ}$.

Cool to cold temperatures are interpreted for the Early Cretaceous of southeastern Australia. Gregory et al. (1989) used oxygen isotope ratios in calcite concretions in the host sediment of fluvial (river deposit) strata in Victoria to suggest mean annual temperatures possibly below zero and certainly below $5^{\circ} \mathrm{C}$. Constantine et al. (1998) interpreted cryoturbation structures (permafrost features) to confirm these temperatures. Rich $e t$ al. (1988) regarded preserved Cretaceous dinosaur fauna to have been superbly adapted to high latitude near polar conditions, tolerating at least 3 months of winter darkness and marked seasonality. Cold temperatures are also indicated by the work of Frakes and Krassay (1992) who recorded ice rafted dropstones in Neocomian-Albian strata in northem Australia in the Carpentaria Basin. Freezing conditions are also suggested by the presence of a tillite in the earliest Cretaceous sequences of the Eromanga Basin (Alley and Frakes 2003). The presence of glendonites in the Eromanga Basin suggests such climatic conditions continued in this basin until the Late Aptian (De Lurio and Frakes 1999) and are also used as evidence for a Late Aptian rise in temperature to $5-8^{\circ} \mathrm{C}$. This is in broad agreement with the Western Australian $\delta^{18} \mathrm{O}$ data of Clarke and Jenkyns (1999) that also shows a significant warming through this time.

Palynological evidence from southeast Australia in the Late Cretaceous suggests that the climate was cool to temperate with high moisture availability (Dettmann 1994). This is in contrast to the north of the continent where Quilty (1994) reports warm to tropical marine faunas on the northwest shelf of Western Australia. Clarke and Jenkyns (1999) suggest a steady cooling on the western continental margin throughout the late Cretaceous. This 
pattem is consistent with global oxygen isotope variations that indicate widespread global cooling near the end of the Cretaceous (Huber 1998).

These broad interpretations may be hiding a finer-scale climate story. Gallagher et al. (2008) show that in the latest Cretaceous in the Gippsland Basin conditions were overprinted by Milankovitch eccentricity and obliquity forced alternations of drier and wetter periods. It is suggested that these drier and wetter periods were either related to the waxing and waning of ephemeral ice sheets in Antarctica during times of insolation maxima and minima or were caused by another unknown mechanism (Miller et al. 2003 , 2004). The palynological data show a consistent trend to drier conditions culminating around $67 \mathrm{Ma}$ near the Cretaceous/Tertiary boundary. However, angiosperm groups, including Nothofagus, that evolved in the Early Cretaceous and spread rapidly during the Late Cretaceous, not only survived the boundary event but went on to achieve prominence in the Cenozoic (Dettmann 1994). As suggested by Wolfe and Upchurch (1986), this perhaps indicates only a brief duration of the impact of winter in the southern hemisphere. The oldest-known mammal on the Australian continent (a platypus-like species) and Australia's oldest birds first appeared in the Cretaceous (Archer et al. 1991)

\section{Palaeogene}

The Palaeogene period includes the Palaeocene, Eocene and Oligocene epochs, and spans the interval from $65.5 \mathrm{Ma}$ to $23.0 \mathrm{Ma}$. It is a period of dominantly wet and humid conditions in Australia with evidence for only restricted arid conditions in the northwest (Martin, 2006). In the Palaeocene, horses, primates and camivores radiated worldwide (Archer et al. 1991). In Australia, the first Casuarinaceae appear in the early Palaeocene, and by the late Palaeocene Banksia and Eucalyptus first occur (Hill 1994).

By the Eocene Australia's marsupials, bats, frogs and snakes became abundant (Archer et al. 1991). Rainforest dominated the continent during this period when the Poaceae first appear (Hill 1994). Temperatures rose into the early Eocene (consistent with a global trend; Zachos et al. 2008) but declined during the mid-late Eocene. The mid-late Eocene was characterised by generally lower average sea-surface temperatures (Gallagher and Holdgate 2000), although intervals of tropical and temperate conditions have been noted in the westem half of the continent by Quilty (1994) and Apthorpe (1988). The late Eocene-early Oligocene was characterised by cool and wet conditions, with many regions characterised by cool temperate rainforest (Benbow et al. 1995). Martin (2006) attributes this change to strengthening of the Antarctic Circumpolar Current reducing heat transfer from the equatorial latitudes to higher latitudes.

The cooling trend continued into the Oligocene, which is characterised by cool and dry 'icehouse' conditions (Moss and MoGowran 2003), before a significant warming event the end of the Late Oligocene. By the Oligocene, koalas, kangaroos and other modem marsupials were well established and there is evidence for diverse forest-dwelling faun at this time (Archer et al. 1991). Evidence suggests that seasonality became important during the Oligocene, particularly in southeastern Australia.

In detail, regions of Australia show different local trends throughout the Palaeogene.
In northwestern Australia, the early Palaeocene was a time of relatively high rainfall, although total rainfall was variable and there is some evidence for local aridity in the north (Truswell and Harris 1982; Apthorpe 1988). Macphail (1997) suggests the flora, and therefore climatic conditions, in northwestern Australia in the Palaeocene were similar to those in southern Australia. In the early Eocene, mean temperatures in the north increased and the arid conditions that developed in the early Palaeocene were enhanced. At the same time further south temperatures decreased and humidity increased (Martin 2006). Apthorpe (1988) suggests that rainfall decreased into the late Eocene, although preservation of Nothofagus pollen suggests isolated pockets of rainfores remained at this time (Truswell and Haris 1982). In the middle Oligocene an extensive laterite formed in Western Australia associated with a drop in sea level and possibly a trend to seasonal humidity (Quilty 1994). By the late Oligocene, warm tropical conditions were in place across much of northwestern Australia (Quilty 1994).

In northeastem Australia climatic conditions in the Palaeocene ranged from subtropical to temperate (Feary et al. 1991). Temperatures continued to rise throughout the Palaeocen into the early Eocene until subtropical conditions were widespread. In the mid- to late Eocene mean temperatures began to decrease and temperate conditions prevailed (Feary et al. 1991). Rainforest persisted in isolated pockets. The Oligocene was a period of temperate conditions with decreasing mean annual temperatures. The late Oligocene climatic conditions have been debated in the literature. Arid conditions characterised by high average temperatures and low rainfall have been suggested by Megirian (1992), whereas Creaser (1997) suggested high rainfall conditions. Palynological evidence suggests warm climatic conditions in much of coastal Queensland at this time (Macphail et al. 1994).

In the early Palaeocene of central Australia warm temperate climatic conditions with high seasonal rainfall have been reported by Quilty (1994). Sluiter (1991) suggests mean annual temperature of $18-19^{\circ} \mathrm{C}$ and mean precipitation in excess of $1400 \mathrm{~mm}$, significantly cooler and wetter than the modern climatic regime (Figure 12.1 ). The early Eocene basins throughout central Australia, including the Torrens and Lake Eyre Basins, record palynological evidence for rainforest flora but the general absence of Nothofagus suggests rainfall was seasonal and points towards a dry season. By the late Eocene, rainfall had decreased significantly (Truswell and Harris 1982)

In southeastem Australia the late Eocene to early Oligocene was a period of high rainfall conditions, with abundant Nothofagus in cool temperate rainforests (Benbow et al. 1995) and the accumulation of thick peat and coal sequences in the Gippsland Basin (e.g. Holdgate et al. 2009). Pole et al. (1993) suggest that the late Oligocene-early Miocene was the beginning of seasonal conditions in southeastern Australia based on the presence of both open and closed-forest flora in the sediments southeast of Melbourne. In the Murray Basin the presence of Nothofagus and swamp-forest taxa suggests dominantly high rainfall conditions (Martin 1993).

\section{Neogene}

The Neogene period includes the Miocene, Pliocene, Pleistocene and Holocene epochs, and spans the interval from $23.0 \mathrm{Ma}$ to the present day. The first Acacia appear in the 
early Miocene. The Poaceae, that first appeared in the Eocene, became common by late Miocene time (Hill 1994).

\section{Miocene}

A number of observations suggest significant warming from the late Oligocene into the A num early and middle Miocene across Austratia. conditions. Evidence for such early to middle Miocene 'greenhouse' conditions includes:

1. the occurrence of tropical foraminiferal taxa in Miocene marine sediments of southeastern Australia (e.g. Li et al. 1996; Gallagher et al. 2001; Gallagher and Gourley 2007) and the observed variation in stable isotope ratios of foraminifera globally (Zachos et al. 2001).

2. the development of a prominent, regionally extensive Miocene-Pliocene ferricrete weathering surface in many parts of Australia. Examples include the Karoonda Surface ferricrete in the Murray Basin (Firman 1973), a prominent ferricrete developed on Cambrian sediments of the Officer Basin of northern South Australia (Drexel and Preiss 1995); ferricretes in the Lake Eyre Basin (Alley 1998) and the Eucla Basin (Wing Drexel and Preiss 1995); silcretes in central Victoria (Webb and Golding 1998); the Timboon surface ferricrete in western Victoria (Kenley 1971) and a prominent saprolite in the Cobar region of NSW (Smith et al. 2009).

3. palynological data suggesting the presence of extensive temperate rainforest (e.g. Ke a ce al. 1994), particularly in eastern Australia, and the general absence of grasslands and/or open sclerophyll forest (Kershaw et al. 1994).

These 'oreenhouse' conditions persisted through the early and middle Miocene. The late These 'greenhouse' conditions perith a significant decrease Miocene was again characterised by dricr icehouseconditions wh a significant decrease in sea-surface temperatures (Gallagher et al. 2001; Zachos et al. 2001). In detail, there is considerable variation across the regions.

In northeastem Australia, Archer et al. (1989), Travouillon et al. (2009) and others use in norting the presence of key rainforest-indicative mammals and high faunal diversity at Riversle to argue for a relatively warm and we Miocene. In the northwest of the continent, Macphail (1997) estme rainfall in the Miocene was in the range of 600-1500 $\mathrm{mm}$ and in parts of northeast Australia was greater than $3000 \mathrm{~mm}$. From the late Palaeogene to the middle Miocene climate is was greater than $3000 \mathrm{~mm}$. From the laty seasonal and there is palynological evidence for around a $50 \%$ reduction in mean annual rainfall from the early Miocene to the Pliocene (Macphail 1997). Pollen studies of late-Miocene-aged sediments offshore from northwesem Australia support this, suggesting that coastal vegetation was dominated by em Australia support this, Archer et al. Casuarinaceae rather than rainforest species (Martin and McMinn 1994). Archer et the (1991) suggests that tectonic collisions to the north of the Austral

Miocene permitted the arrival of rodent species for the first time.

Central Australia was characterised by the presence of extensive shallow lakes in the early to middle Miocene (when it was situated around $40-45^{\circ} \mathrm{S}$ ) pointing towards muc higher rainfall than present. Evidence from the Lake Eyre Basin suggests widespread higher rainfall than present. Evidence flon 1998; Martin 2006). These wet condition were accompanied by high humidity as indicated by stromatolitic sediments and ooidal grainstones (Martin 2006). Macphail et al. (1994) suggests there was also significan seasonality. By the late Miocene there is palynological evidence for increased dry open woodland and chenopod shrubland (Benbow et al. 1995).

In southeastern Australia pollen studies in the Gippsiand Basin suggest a dominantly humid climate in the early-middle Miocene with mean average temperatures around $5^{\circ} \mathrm{C}$ higher than today and annual rainfall $>1500 \mathrm{~mm}$ (Kershaw 1997). Similarly, in the Murray Basin the early-middle Miocene was a period of high diversity of plant species, suggesting widespread warm conditions (Martin 1993). In the late Miocene of southem Victoria there were small pockets of Nothofagus rainforest remaining but the general disappearance of rainforest taxa suggests a trend to increasingly arid conditions at this time (Kershaw et al. 1994; Martin 1994). These rainforest communities were replaced by widespread wet sclerophyll forest (Martin 1994).

\section{Pliocene-Pleistocene}

Across the continent the Pliocene-Pleistocene was a time of highly variable climatic conditions and a trend to profound and dramatic long-term climatic change. In general, rainfall declined from the early Pliocene to the middle-late Pliocene and conditions became increasingly arid. This drying trend was briefly reversed in the early Pliocene with a wet and humid interval marked by the re-establishment of some rainforest communities in the Murray Basin (e.g. Martin 1989) and in the area around Lake George in southern New South Wales (e.g. McEwen Mason 1991). As in the late Miocene, rainforest was replaced by wet sclerophyll forest. By the late Pleistocene, fully arid conditions were widespread across much of the Australian continental interior (e.g. Kershaw et al. 1991; Wagstaff et al. 2001) and the first significant grassland communities were established (Hill 1994). Specialist grazing animal species evolved during the Pliocene. By the Late Pleistocene most megafauna species became extinct (Archer et al. 1991).

In southern Western Australia Lake Lefroy, part of a chain of playa lakes in the Yilgam Craton, was a semi-permanent lake with seasonal dryness in the Pliocene (Zheng et al. 1998) suggesting a greater availability of surface water at that time. The early Pliocene sediments of nearby Lake Tay record a similar set of conditions and a palynological assemblage dominated by sclerophyll woodland with only minor rainforest taxa (Bint 1981; Hill 1994). A detailed palynological study of palaeolake Yallalie in southern Western Australia reveals a dominantly warm and seasonally wet climate in the middle Pliocene from at least 3.51 Ma until 2.5 Ma (Dodson and Ramrath 2001). This record however, was one which was interrupted by at least three distinct periods of arid conditions between 2.90 and $2.56 \mathrm{Ma}$, as indicated by an increase in the abundance of chenopod shrubland pollen (Dodson and Macphail 2004) and observed changes in sediment particle size (Dodson and Lu 2005). Dodson and Ramrath (2001) also suggest periods of greater seasonality between 2.96 and $2.82 \mathrm{Ma}$

In central Australia Lake Amadeus preserves a sequence of fluvial-lacustrine clays (the Uluru Clay) of Pliocene age, suggesting the presence of perennial surface water at that time. The Ulun Clay is overlain by the Winmatti Beds, a sequence of saline 
gypsiferous playa sediments that signifies a major change in climatic conditions some time in the Plio-Pleistocene (Chen et al. 1993). Similarly, the preservation of a thick sequence of uniform lacustrine clay (the Anmatyerre Clay) in Lake Lewis in centra Australia indicates generally wetter conditions during much of the Pleistocene (English et al. 2001). These lacustrine clays are overlain by evaporitic sediment of the Tilmouth Beds, again suggesting a dramatic change in climatic conditions at some stage in the middle-late Pleistocene. Lake Frome, in northem South Australia, records evidence for an early Pliocene open sclerophyll forest as well as freshwater swamp environments (Martin 1990). By the late Pliocene, arid shrublands had expanded across centra Australia but some restricted wetland environments persisted (Martin 2006). Fujioka et al. (2005) claim that the early-middle Pliocene was the time at which the first stony deserts began to develop in central Australia based on in situ cosmogenic dating of relic gibber pavements. In central Australia, the development of extensive desert dune system from the late Pleistocene until the present is well documented from geomorphological and sedimentological data (e.g. Chen et al. 1991; Herczeg and Chapman 1991; Nanson et al. 1992; Hesse et al. 2004; Fitzsimmons et al. 2009).

In northem Australia, tropical conditions prevailed in the early Pliocene with high average sea-surface temperatures (Quilty 1994). Temperatures in the northwest of the continent were higher than during the Miocene but there is no evidence for a significant temperature change in the northeast of the continent. In the northeast and the northwest there is palynological evidence for the first appearance of grassland environments in the early Pliocene (Martin and McMinn 1994). By the late-Pliocene rainfall in northern Australia was approaching modern-day averages and grassland communities were well established and widespread (Hill 1994)

In southeastern Australia the earliest Pliocene was a period of warm and wet conditions. Macphail (1997) estimated a mean early Pliocene annual temperature of $20^{\circ} \mathrm{C}$ and rainfall $>1000 \mathrm{~mm}$. Pollen data from southwestern Victoria suggest high rainfal conditions up until 4.46 Ma (e.g. Macphail 1997). The late Pliocene in this region was cooler and characterised by more variable climatic conditions (Gallagher et al. 2003); by this time even relict rainforest communities had disappeared, sclerophyll forests were well established and there was a significant trend to open grassland and woodland as indicated by an increased abundance of Eucalyptus and Asteraceae pollen (Kershaw et al. 1991, 1994). This change is thought to have occurred even earlier, possibly in the middle Miocene-early Pliocene, on the Eyre Peninsula of South Australia (Truswell and Harris 1982)

In the late Pliocene of the Murray Basin in southeastern Australia, megalake Bungunnia (Figure 12.3) covered an area of more than $50000 \mathrm{~km}^{2}$ (McLaren et al. 2009 ) and is one of the largest known palaeo- or modern lakes in an intracontinental setting. Palaeomagnetic analyses suggest the lake formed at $2.4 \mathrm{Ma}$ (McLaren et al. 2009). Although lake formation is in part due to regional uplift defeating continentalscale drainage systems (e.g. Fiman 1965; Stephenson 1986), its existence implies that average rainfall over the Murray-Darling catchment during the early Pliocene must have been at least $2-3$ times that of the modern day (Stephenson 1986). Preliminary analysis of the variation in clay minerals within the Blanchetown Clay suggests cyclic variations in

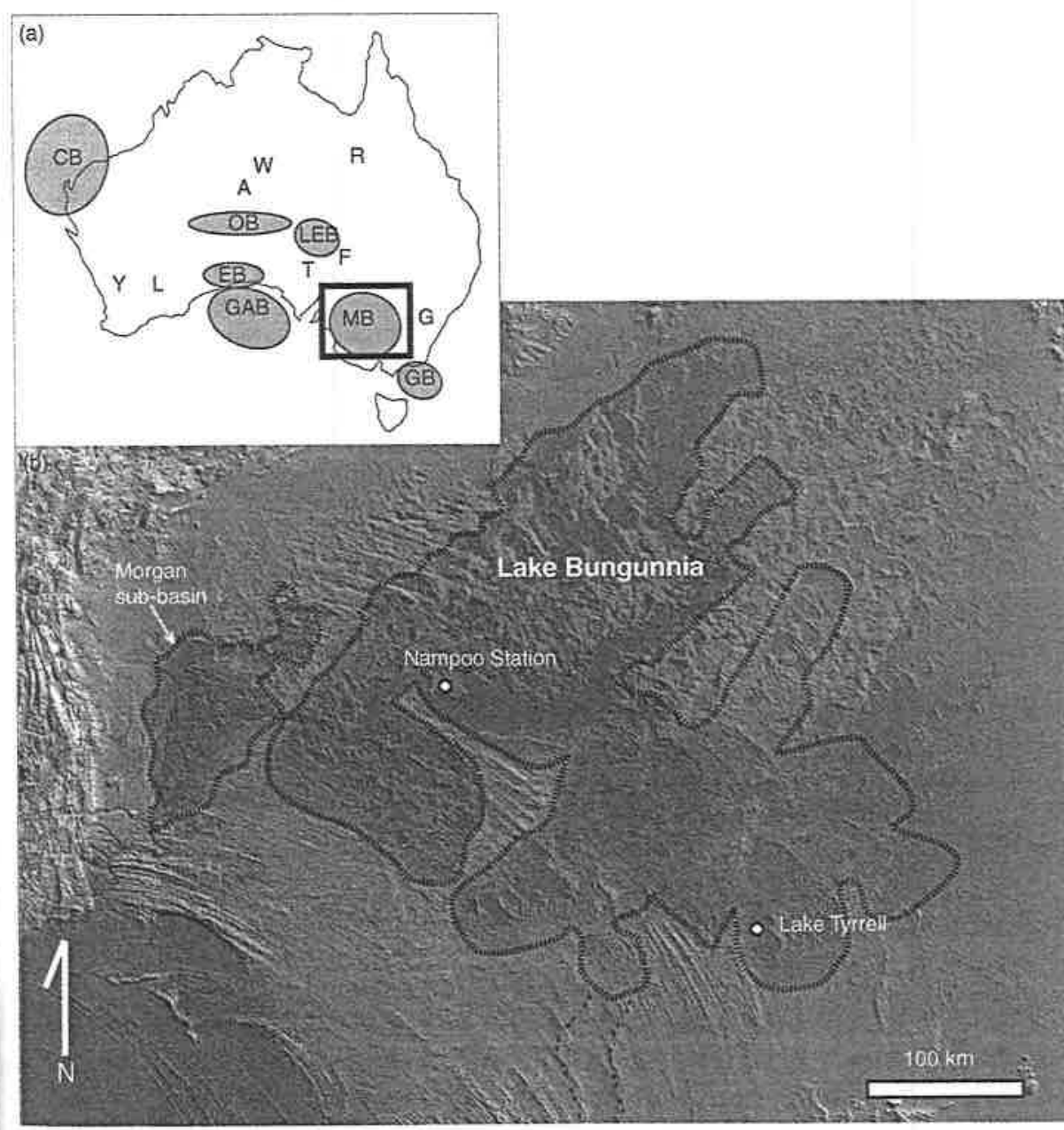

Fgure 12.3 (a) Location map showing approximate position of basins mentioned in the text, $\mathrm{CB}=\mathrm{Carnarvo}$ Basin, $\mathrm{OB}=$ Officer Basin, LEB = Lake Eyre Basin, $\mathrm{EB}=$ Eucla Basin, $\mathrm{GAB}=$ Great Australian Basin, $\mathrm{OB}=$ Officer Basin, LEB = Lake Eyre Basin, $\mathrm{EB}=$ Eucla Basin, $\mathrm{GAB}=$ Great $\mathrm{A}$
Bight $\mathrm{MB}=$ Murray Basin, $\mathrm{GB}=$ Gippsland Basin and localities mentioned in the text, Bight, MB = Murray Basin, $\mathrm{GB}=$ Gippsland Basin and localities mentioned in the text,
$\mathrm{Y}=$ palaeolake Yallalie, $\mathrm{R}=$ Riversleigh, $\mathrm{T}=$ Lake Torrens, $\mathrm{F}=$ Lake Frome, $\mathrm{G}=$ Lake George, $\mathrm{A}=$ Lake Amadeus, $\mathrm{W}=$ Lake Lewis, $\mathrm{L}=$ Lake Lefroy. Box indicates location of (b). (b) SRTM data showing the interpreted size of Lake Bungunnia, illustrated at its maximum extent (modified from McLaren et al. 2009 and McLaren and Wallace 2010).

climate during the lake's existence - possibly correlating to major glacial-interglacial cycles - but overall warm and wet climatic conditions (McLaren et al. 2009).

Elsewhere in southeastem Australia, palynological data suggests these wet conditions persisted until at least the early Pleistocene. Sniderman et al. (2007) report pollen data 
suggesting wet and humid conditions until at least 1.6 Ma. By the middle Pleistocene there is evidence for a change to more arid conditions. For example, Wagstaff et al. (2001) present pollen data from western Victoria demonstrating widespread dry land vegetation at this time, while White and Mitchell (2000) suggest the widespread development of coastal dunes at this time in eastern Victoria reflected dry conditions with limited vegetation development. A trend to arid climatic regimes is also suggested by the dominantly carbonate mineralogy of the youngest Lake Bungunnia sediment, the Bungunnia Limestone (McLaren and Wallace 2010). This sediment is younger than the main sedimentary fill of the lake and is therefore younger than $1.2 \mathrm{Ma}$. Precipitation of evaporitic minerals such as gypsum and magnesite points to profound change in climatic conditions at some time in the Plio-Pleistocene.

\section{Late Pleistocene}

There is abundant evidence for pronounced arid glacial and wet interglacial cycles within the late Pleistocene, particularly from high-resolution pollen and isotope records. During glacial episodes increased aeolian sedimentation is noted while from one glacial cycle to the next a trend to increasing severity of aridity is observed. Pollen data reviewed by Kershaw et al. (2003) shows a significant trend towards arid climates beginning around $350 \mathrm{ka}$. Hesse (1994) notes a significant increase in the long-wavelength dust component in sediments of the Tasman Sea, between Australia and New Zealand, at around the same time. Kershaw and Nanson (1993) suggest the greatest aridity occurred between 27 and $17 \mathrm{ka}$.

\section{Onset of aridity}

The development of arid conditions in Australia is thought to largely reflect global cooling in the Cenozoic; however, the nature and timing of the shift to arid climatic conditions across the continent has remained highly controversial. Unfortunately, there are very few continuous sequences that provide a window into the key period from the wet and humid conditions of the late Miocene to the fully arid conditions of the early Pleistocene. Consequently, the timing and mechanism of climatic change in this interval has remained an area of active research endeavour and there has been considerable debate in the literature.

A number of scenarios have been proposed for the timing of initiation and spread of arid climatic conditions. Beard (1977) suggested the arid shift was simply a product of northward tectonic motion bringing the northwest of the continent into high-pressure atmospheric conditions. Kemp (1978) suggested the formation of the Antarctic Circumpolar current following the break-up of Australia and Antarctica was the greatest influence on climate and that arid conditions were initiated soon after break-up and the establishment of this oceanic circulation system. Consequently, Kemp (1978) suggested aridity began in the centre of the continent in the late Eocene and expanded toward the coastal regions.

Our contemporary understanding of the trend to arid climatic regimes in the Cenozoic is based largely on the work of Bowler $(1976,1982)$ and Martin $(1978)$ together with a large body of more recent work that builds upon and extends these earlier observations (e.g. Chen and Barton 1991; Kershaw et al. 1991; Macphail 1997; Dodson and Macphail 2004; Fujioka et al. 2009). Based principally on the apparent timing of contraction of large lakes, as well as documented vegetation changes, it is now generally accepted that the general trend toward aridification of the Australian continent began sometime in the late Miocene, and increased in amplitude into the PlioPleistocene. Bowler (1982) suggested arid climatic conditions developed fitst in southern Australia with aridity subsequently expanding northwards. Globally, the Plio-Pleistocene is known to be a time of great climatic change (e.g. Clark et al. 2006) and a trend to increasingly arid climates across the globe in this period is reflected by the development of the Atacama Desert around $3 \mathrm{Ma}$ (Hartley and Chong 2002), major step-like increases in aridity in Africa around $2.8 \mathrm{Ma}$ and 1.7 Ma (deMenocal 2004) and the establishment of a permanent northern hemisphere ice sheet (e.g. Lear et al. 2000; Kulhmann et al. 2006).

In detail, geological observations suggest that there was considerable diachroneity in the timing of development of arid conditions across the Australian continent. In this section we summarise current knowledge of the timing and origins of this critical climatic shift.

\section{Northern and western Australia}

The identification of three distinct episodes of short-lived aridity, marked by the first appearance of semi-arid zone flora and halophytic diatoms, between 2.90 and $2.56 \mathrm{Ma}$ in palaeolake Yallalie led Dodson and Macphail (2004) and Dodson and Lu (2005) to suggest that a trend to increasing amplitude arid climatic cycles in southern Western Australia began around $2.5 \mathrm{Ma}$. Lake Lefroy preserves evidence of a significant hydrological transition from the freshwater Revenge Formation to the evaporitic and gypsiferous units of the Roysalt Formation; Zheng et al. (1998) reported magnetostratigraphic data to suggest this transition, and by inference the onset of fully arid conditions, occurred within the Brunhes Normal Polarity Chron at $<780 \mathrm{ka}$. However, the Pleistocene age for the onset of arid conditions presented by Zheng et al. (1998) is very different from an early Pliocene age suggested by a palynological study of the same sequence by Clarke (1993) and the magnetostratigraphic constraints continue to be debated (e.g. Clarke and Pillans 2002).

\section{Central Australia}

For central Australia, Chen and Barton (1991) present magnetostratigraphic data for the sediments of Lake Amadeus to constrain the time of onset of aridity, as indicated by the transition from the perennial lacustrine Uluru Clay to the saline sediments of the Winmatti Beds. Chen and Barton's (1991) magnetostratigraphic data suggests that arid climatic conditions began at either $0.9 \mathrm{Ma}$ or $1.6 \mathrm{Ma}$, significantly earlier than the Brunhes-Matuyama transition. English et al. (2001) support the interpretation of a c. 1 $\mathrm{Ma}$ age for this change and suggest it is the earliest expression of arid climates in central Australia. In Lake Lewis the transition from perennial lacustrine sediments to saline 
sediments seems to occur much later, at a time well into the Brunhes chron. English et al. (2001) suggest this difference reflects local hydrology, including the catchment/lake area ratio, and the type of feeder drainage systems for each of the lakes.

Cosmogenic ${ }^{10} \mathrm{Be}$ and ${ }^{26} \mathrm{Al}$ measurements from desert dunes in the westem Simpson Desert of central Australia suggest an increase in amplitude of aridity at $c .1 \mathrm{Ma}$ (Fujioka et al. 2009). In an earlier study, Fujioka et al. (2005) presented cosmogenic ${ }^{21} \mathrm{Ne}$ and ${ }^{10} \mathrm{Be}$ data to suggest the first stony deserts developed in central Australia around 2-4 Ma.

\section{Southeastern Australia}

Two particularly influential contributions to our understanding of the onset of aridity in Australia are those of Bowler $(1976,1982)$. These contributions use the stratigraphic record of Lake Bungunnia in southeastern Australia (Figure 12.3) to understand the continental shift to arid climatic regimes. Although terrestrial sediments generally provide a more fragmented record of palaeoclimate (Martin 2006) the sediments of Lake Bungunnia provide one of the most continuous records of terrestrial sedimentation in the critical Plio-Pleistocene interval. Lake Bungunnia is also important because it was areally extensive but shallow, and so once formed would have been particularly sensitive to climatic changes in terms of total precipitation and evaporation over the lake as well as volumes and rates of discharge from feeder river systems. Following the work of Bowler (1982) the stratigraphic sequence preserved in Lake Bungunnia has become effectively a type section for understanding the onset of arid conditions in the Australian continent. Sediments of Lake Bungunnia consist of the variable (1-40 m) thickness Blanchetown Clay, the main depositional unit of the lake, and a thin (1-3 m) younger lacustrine carbonate unit, termed the Bungunnia Limestone (Fiman 1965; Brown and Stephenson 1991). McLaren and Wallace (2010) have shown that the Blanchetown Clay is comprised of a number of distinct sedimentary units, which can be correlated regionally: (1) well-sorted massive to cross-laminated sands with interbedded clay; (2) grey-green to red-brown laminated to unlaminated clay; and (3) laminated to massive grey-white quartz-silt (Nampoo Member of McLaren et al. 2009; Figure 12.4).

Remnants of megalake Bungunnia remain in the modern environment in the form of small saline playas (Howchin 1929) and it is this dramatic contraction of the lake that has previously been proposed to herald the onset of fully arid climatic regimes (Bowler 1982). The paper by An et al. (1986) subsequently provided magnetostratigraphic data to suggest that the age of the youngest Lake Bungunnia sediments, and hence the time of onset of aridity, was around the Brunhes-Matuyama transition (c. 700-800 ka). However, magnetostratigraphic data presented by McLaren et al. (2009) suggest the Blanchetown Clay was deposited entirely within the Matuyama Reversed Chron. Based on the known thickness of normal polarity sediment within the Blanchetown Clay attributed to deposition during the Olduvai Normal Chron, McLaren et al. (2009) have suggested that the oldest lake sediments were deposited at $2.4 \mathrm{Ma}$ and the youngest Blanchetown Clay is as old as $1.2 \mathrm{Ma}$; significantly older than the age of reported by An et al. (1986).

In addition to the improved magnetostratigraphic constraints presented by McLaren et al. (2009), a re-evaluation of the stratigraphy of Lake Bungunnia presented by
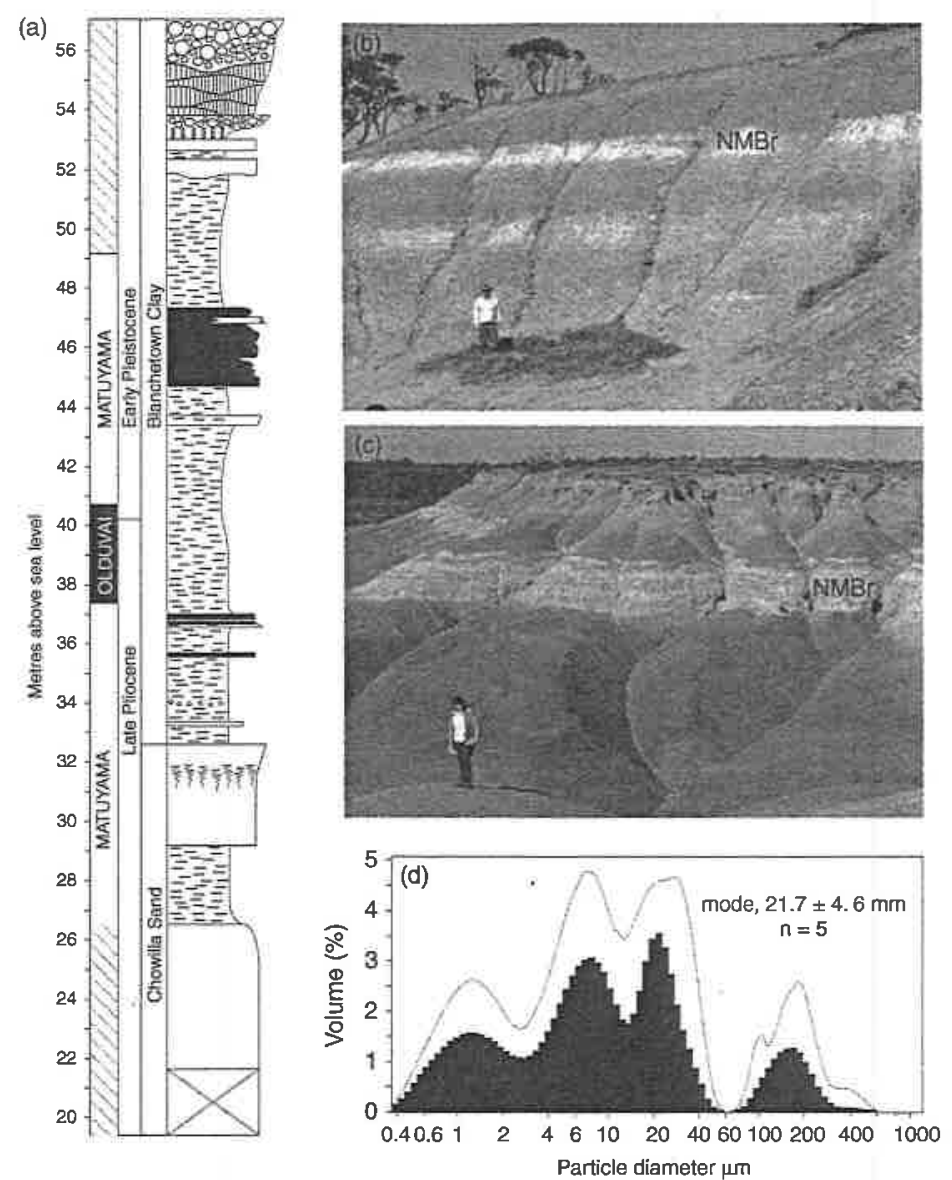

Figure 12.4 (a) Stratigraphic section of Blanchetown Clay from Nampoo Station with age information derived from palaeomagnetic analyses (modified from McLaren et al. 2009 and McLaren and Wallace 2010); (b) outcrop of Blanchetown Clay showing Nampoo Member (NMBr) at Lake Tyrrell; (c) outcrop of Blanchetown Clay showing Nampoo Member (NMBr) at Rufus River; (d) average particle size distributions, obtained using a LS Coulter Particle Size Analyser, for the Nampoo Member silt from Nampoo Station.

McLaren and Wallace (2010) highlights two observations that are central to understanding the trend to arid climatic conditions in southeastem Australia. These observations suggest the onset of arid conditions was step-wise and earlier than previously suggested:

1. Recognition of the Nampoo Member aeolo-lacustrine silt as a regionally extensive correlatable unit across the Lake Bungunnia basin. The morphology of grains within the Nampoo Member suggest that it represents wind-blown dust and/or loess (Figure 12.4). The major grain size mode around $20 \mu \mathrm{m}$ is interpreted to represent 'classic' loess (e.g. Pye 
1987), while the continuum of grains to $<1 \mu \mathrm{m}$, with secondary mode between $4 \mu \mathrm{m}$ and $6 \mu \mathrm{m}$, may represent a high-level long-wavelength dust component or rainout of fine particles adhered to the coarse silt particles (Hesse and McTainsh 2003). The silt-sized grains may have been sourced from either (1) distal 'desert loess', formed and/or stored elsewhere in the continent, possibly in the Central or Westem Australian basins or (2) from the floor of Lake Bungunnia itself, during a dry, low lake-level episode. Similar origins have been proposed for loess in the Saharan desert (e.g. Evans et al. 2004). Regardless of source mechanism, deposition of the Nampoo Member silt-sized grains must reflect significant climate change, heralding a major transition from the wet climatic regimes responsible for formation of the lake, to cold and arid climatic regimes with high average wind speeds to account for both formation of the desert loess in the basin or in surrounding upland regions and/or its transportation to the Lake Bungurnia basin. The loess of the Nampoo Member may be the first sedimentary evidence of the development of extensive desert dune systems in central and/or western Australia. Indeed as noted by Bowler (1976) 'the presence of aeolian sediments ... as dust layers deposited from suspension, provides cogent evidence of arid environments'. Its recognition in Lake Bungunnia constrains a major step in the aridification of the continent. Constraints from magnetostratigraphy suggest this change occurred around 1.5-1.4 Ma (McLaren et al. 2009). This age is consistent with previously documented evidence of wet climates around $1.6 \mathrm{Ma}$ (Sniderman et al. 2007) and dry climates at $1.2 \mathrm{Ma}$ (Wagstaff et al. 2001)

2. Recognition of distinct terrace levels within the basin, which are capped by an ephemera lake facies of varying lithology. The Bungunnia Limestone is preserved on terraces ranging over $20 \mathrm{~m}$ in elevation providing a record of decreasing lake level through time (McLaren and Wallace 2010). This change from clastic to carbonate precipitation records a second major step in the aridification of the continent. The last stages of the evolution of Lake Bungunnia are interpreted to reflect fluctuation between (1) a steady-state open lake system where inflow and outflow (via evaporation and fluvial outwash) were matched and shoreline erosion was occurring within the basin to produce the well-formed terraces, and (2) a closed lake system with high evaporation and no overflow that resulted in carbonate precipitating conditions and the deposition of the Bungunnia Limestone (McLaren et al. 2012). In this interpretation, (1) is likely to correspond with significantly wetter Late Pleistocene interglacial conditions and (2) with arid glacial conditions. Moreover, the sequence of changing mineralogy of the Bungunnia Limestone from calcite and aragonite-dominated to dolomite, gypsum and magnesite-dominated as lake level decreases suggests an increasingly saline and evaporitic influence over time. This is likely to represent an overall trend to increasing aridity, as well as a decrease in the magnitude of fluvial recharge as arid climatic conditions became amplified.

\section{Discussion and conclusion}

The Australian continent records a long and complex record of climatic change with many currently arid regions having experienced much wetter conditions in the geological past. To better understand recent ecological and environmental changes, it is essential to understand the timing and origins of this arid shift. Across the continent, a variety of observations give an age of onset of arid climatic conditions between $2.5 \mathrm{Ma}$ and $<780 \mathrm{ka}$. However it is difficult to directly compare previous estimates as definitions of 'fully arid" and 'trend to arid climates' to which these dates are linked are not necessarily the same from author to author. Moreover, the available data are from a small subset of the area of the continent as a consequence of the limited preservation of sedimentary sequences and/or landforms spanning the appropriate intervals. Available observations do suggest, however, that the onset of arid conditions in the Australian continental interior may have been diachronous. It almost certainly occurred in a step-wise fashion and less rapidly than previously thought.

The stratigraphic sequence represented by the sediments of Lake Bungunnia preserves what is at this time the most complete stratigraphic record of climatic change in the PlioPleistocene in Australia. It suggests that there was a progressive step-wise increase in aridity in southem Australia. The 1.4-1.5 Ma age of the aeolo-lacustrine silts of the Nampoo Member of the Blanchetown Clay dates a major climatic shift across the continent and a major step in the trend to arid climatic regimes. It may also indicate an earlier onset of arid conditions in the centre and west of the continent than in the southeast. Recognition that a major step in the aridification of Australia occurred around $1.5 \mathrm{Ma}$ is consistent with global climate trends and is highly significant for our understanding of climate change in the Plio-Pleistocene. Following this major step toward arid climatic conditions, the record of carbonate precipitation within the Bungunnia Limestone suggests a progressive increase in the amplitude of arid climatic cycles, which culminates probably around the middle Pleistocene. Unfortunately, no biostratigraphic or geochronological techniques have yielded precise age constraints for the Bungunnia Limestone, however the onset of fully arid conditions must be more recent than $c .1 .2 \mathrm{Ma}$.

The work of Chen and Barton (1991) in central Australia and that of Zheng et al. (1998) in western Australia are the other major studies to attempt to directly date sediments spanning the transition from wet to arid climates. The $c .1 .5 \mathrm{Ma}$ age for the onset of arid conditions in southeastern Australia is similar to one interpretation of the magnetostratigraphic data from central Australia presented by Chen and Barton (1991) suggesting isochronous continent-scale climatic change leading up to the mid-Pleistocene transition. However, Chen and Barton's (1991) altemate interpretation of a $0.9 \mathrm{Ma}$ age for the onset of aridity in central Australia cannot be discounted based on the available data. Moreover, in western Australia a significant range of ages has been presented for the onset of arid conditions. These data suggest that there is at least some spread in the age of onset of arid climatic conditions across the continent and in many ways this is not unexpected given the size of the continent and the number of different climate influences. Importantly, the new data from Lake Bungunnia are of a higher sensitivity compared to other datasets and so have the capacity to track step-wise changes that may have been missed in other studies. Moreover, the fact that other studies are less sensitive means that it is not clear whether the age data obtained from them is faithfully recording the age of transition of climatic regime or one step in what may plausibly be a series of step-wise changes.

The cause of the trend to arid climatic conditions in Australia is also debated. The trend

to arid climatic regimes must, at least in part, reflect global cooling in the Cenozoic, the 
result of increasing total global ice volumes (e.g. Head and Gibbard 2005) as well as changes in relief, such as the uplift of the Tibetan Plateau (e.g. Ruddiman and Kutzbach 1989). In Australia, change in this interval must be closely tied to ice build-up in Antarctica and major changes in atmospheric circulation following intensification of the Antarctic Circumpolar current. Evidence for a step-wise change may suggest a complex interplay between global climate cycles, regional climate drivers, such as ENSO activity, and local factors, including the impact on total rainfall in the continental interior of the retreat of the Miocene sea from the Murray Basin (Kershaw et al. 1994) and the uplift of the Eastern Highlands beginning in the late Eocene and continuing into the Pliocene (Holdgate et al. 2008)

In terms of most recent climate change in the late Pleistocene, Hesse et al. (2004) suggest that in northern Australia changes in the location and intensity of tropical convergence have had the most influence, while in southern Australia changes in the SAM (rather than the subtropical ridge) have had a more significant impact on climate. Kershaw et al. (2003) suggest latest Pleistocene and Holocene drying was the result of atmospheric changes due to ongoing collision in southeast Asia, the effect of ice volume induced global glacialinterglacial cyclicity, as well as changes in the frequency and activity of ENSO.

Although the new data from Lake Bungunnia has significantly improved our understanding of the timing of the onset of arid climatic conditions, there remains much work to be done refining the timing of the change across the continent as well as the factors that were responsible for it

\section{References}

Allan, R., J. Lindesay and D. Parker (1996). El Nino Southern Oscillation and Climatic Variability. Melbourne, Australia: CSIRO Publishing.

Alley, N. F. (1998). Cainozoic stratigraphy, palaeoenvironments and geological evolution of the Lake Eyre Basin. Palaeogeography, Palaeoclimatology, Palaeoecology 144: 239-263.

Alley, N. F. and L. A. Frakes (2003). First known Cretaceous glaciation: Livingston Tillite Member of the Cadna-owie Formation, South Australia. Australian Journal of Earth Sciences 50 139-144.

An Z J. M. Bowler, N. D. Opdyke, P. G. Macumber and J. B. Fiman (1986). Palaeomagnetic stratigraphy of Lake Bungunnia: Plio-Pleistocene precursor of aridity in the Murray Basin southeastem Australia. Palaeogeography, Palaeoclimatology, Palaeoecology 54: 219-239.

Apthorpe, M. C. (1988). Cenozoic depositional history of the North West Shelf. In P. G. Purcell and R. R. Purcell (eds), The North West Shelf Australia: Proceedings of the Petroleum Exploration Society of Australia Symposium. Perth, Australia: Petroleum Exploration Society of Australia, pp. 55-84.

Archer, M., H. Godthelp, S. J. Hand and D. Megirian (1989). Fossil mammals of Riversleigh, Northwestern Queensland: preliminary overview of biostratigraphy, correlation and environmental change. Australian Zoologist 25: 29-65.

Archer, M., S. J. Hand and H. Godthelp (1991). Riversleigh: The Story of Animals in Ancient Rainforests of Inland Australia. Kew, Australia : Reed Books.

Barron, E. J. (1983). Warm equable Cretaceous, the nature of the problem. Earth Science Review 19: $305-338$
Barron, E. J. and W. H. Peterson (1991). The Cenozoic ocean circulation based on ocean General Circulation Model results. Palaeogeography, Palaeoclimatology, Palaeoecology 83: 1-28.

Beard, J. S. (1977). Tertiary evolution of the Australian flora in the light of latitudinal movements of the continent. Journal of Biogeography 4: 111-118.

Behera S. K. and T. Yamagata (2001). Subtropical SST dipole events in the southem Indian ocean. Geophysical Research Letters 28: 327-330.

Benbow, M. C., N. F. Alley, R. A. Callan and D. R. Greenwood (1995). Geological history and palaeoclimate. In J. F. Drexel and W. V. Preiss (eds) The Geology of South Australia, Volume 2: The Phanerozoic. Adelaide, Australia: Geological Survey of South Australia Bulletin 54, pp. 208-217.

Bint A. N (1981). An early Pliocene assemblage from Lake Tay, south-western Australia and its phytogeographic implications. Australian Journal of Botany 29: 277-291.

Bobe, R. and A. K. Behrensmeyer (2004). The expansion of grassland ecosystems in Africa in relation to mammalian evolution and the origin of the genus Homo. Palaeogeography. Palaeoclimatology, Palaeoecology 207: 399-420.

Bowler, J. M. (1976). Aridity in Australia: age, origins and expression in aeolian landforms and sediments. Earth Science Reviews 12: 279-310.

Bowler, J. M. (1982). Aridity in the late Tertiary and Quaternary of Australia. In W. R. Barker and P. J. M. Greenslade (eds), Evolution of the Flora and Fauna of Arid Australia. Adelaide, Australia: Peacock Publications, pp. 35-45.

Brown C. M. and A. E. Stephenson (1991). Geology of the Murray Basin. Bureau of Mineral Resources Bulletin 235: 430.

Cane, M. A. and P. Molnar (2001). Closing of the Indonesian seaway as a precursor to east African aridification around 3-4 million years ago. Nature 411: 157-162.

Chen X Y and C. E Barton (1991). Onset of aridity and dune-building in central Australia: sedimentological and magnetostratigraphic evidence from Lake Amadeus. Palaeogeography. Palaeoclimatology, Palaeoecology 84: 55-73.

Chen, X. Y., J. M. Bowler and J. W. Magee (1991). Aeolian landscapes in central Australia: gypsiferous and quartz dune environments from Lake Amadeus. Sedimentology 38: 519-538.

Chen X Y J M Bowler and I W Magee (1993). Late Cenozoic stratioraphy and hydrologic history of Lake Amadeus, a central Australian playa. Australian Joumal of Earth Sciences 40: 1-14.

Clark, P. U., D. Archer, D. Pollard et al. (2006). The middle Pleistocene transition: characteristics, mechanisms, and implications for long-term changes in atmospheric $\mathrm{pCO}_{2}$. Quaternary Science Reviews 25: 3150-3184.

Clarke J D A (1993) Stratigraphy of the Lefroy and Cowan Palaeodrainages, Western Australia Journal of the Royal Society of Western Australia 76: 15-22.

Clarke, J. D. A. and B. Pillans (2002). Comment on 'Onset of aridity in southem Western Australia: a preliminary palaeomagnetic appraisal' by Zheng et al. [Global and Planetary Change 18 (1998) 175-1871. Global and Planetary Change 32: 279-282.

Clarke, L. J. and H. C. Jenkyns (1999). New oxygen isotope evidence for long-term Cretaceous climatic change in the southern hemisphere. Geology 27(8): 699-702.

Constantine, A., A. Chinsamy, P. Vickers-Rich and T. H. Rich (1998). Periglacial environments and polar dinosaurs. South African Journal of Science 94: 137-141.

Creaser, P. (1997). Oligocene-Miocene sediments of Riversleigh: the potential significance of toporat Memoirs of the Queensland Museum, 41(2): 303-314.

deMenocal, P. B. (1995). Plio-Pleistocene African Climate. Science 270: 53-59. 
deMenocal, P. B. (2004). African climate change and famal evolution during the PliocenePleistocene. Earth and Planetary Science Letters 220: 3-24.

De Lurio, J. L. and L. A. Frakes (1999). Glendonites as a paleoenvironmental tool: implications for the early Cretaceous high-latitude climates in Australia. Geochimica et Cosmochimica Acta 63 (7/8): 1039-1048

Dettmann, M. E. (1994). Cretaceous vegetation: the microfossil record. In R. S. Hill (ed.), History of the Australian Vegetation: Cretaceous to Recent. Cambridge: Cambridge University Press, pp. 143-170.

Dodson, J. R. and H. Y. Lu (2005). Salinity episodes and their reversal in the late Pliocene of southwestern Australia. Palaeogeography, Palaeoecology, Palaeoclimatology 228: 296-304.

Dodson, J. R. and M. K. Macphail (2004). Palynological evidence for aridity events and vegetation change during the Middle Pliocene, a warm period in Southwestern Australia. Global and Planetary Change 41: 285-307.

Dodson, J. R. and A. Ramrath (2001). An Upper Pliocene lacustrine environmental record from south-western Australia: preliminary results. Palaeogeography, Palaeoclimatology, Palaeoecology 167: 309-320.

Douglas, R. G. and S. M. Savin (1975). Oxygen and carbon isotope analyses of Cretaceous and Tertiary foraminifera from the central north Pacific. Initial Report of the Deep Sea Drilling Project Volume XVI, 591-605.

Drexel J. F. and Preiss W. V. (eds), (1995). The Geology of South Australia, Volume 2: The Phanerozoic. Adelaide, Australia: Geological Survey of South Australia Bulletin 54.

Edwards, D. L., J. D. Roberts and J. S. Keogh (2007). Impact of Plio-Pleistocene arid cycling on the population history of a southwestern Australian frog. Molecular Ecology 16: 2782-2796.

English, P., N. A. Spooner, J. Chappell, D. G. Questiaux and N. G. Hill (2001). Lake Lewis basin, central Australia: Environmental evolution and OSL chronology. Quaternary International 83-85: 81-101.

Evans, R. D. I F. Jefferson, R. Kumar K. O-Hara-Dhand and I. J. Smalley (2004). The nature and early history of airbome dust from North Africa; in particular the Lake Chad basin. Journal of African Earth Sciences 39: 81-87.

Feary, D. A., P. J. Davies, C. J. Pigram and P. A. Symonds (1991). Climatic evolution and control on carbonate deposition in northeastem Australia. Palaeogeography, Palaeoclimatology, Palaeoecology 89: 341-361.

Firman, J. B. (1965). Late Cenozoic lacustrine deposits in the Murray Basin, South Australia. Quarterly Notes of the Geological Survey of South Australia 16: 1-2.

Firman, J. B. (1973). Regional stratigraphy of surficial deposits in the Murray Basin and Gambier Embayment. Geological Survey of South Australia Report of Investigations 39.

Fitrimmons K E J. W. Magee and K. J. Amos (2009). Characteristion of aeolian sediments from the Strzelecki and Tirari Deserts, Australia: implications for reconstructing palaeoenvironmental conditions. Sedimentary Geology 218: 61-73.

Frakes, L. A. and A. A. Krassay (1992). Discovery of probable ice-rafting in the Late Mesozoic of the Northem Teritory and Queensland. Australian Journal of Earth Sciences 39: 115-119.

Frakes, L. A J E Francis and J. I Syktus (1992). Climate Modes of the Phanerozoic: The History of the Earth's Climate over the Past 600 Million Years. Cambridge: Cambridge University Press.

Fujioka, T., J. Chappell, L. K. Fifield and E. J. Rhodes, (2009). Australian desert dune fields initiated with Pliocene-Pleistocene global climatic shift. Geology 37: 51-54.

Fujioka, T., J. Chappell, M. Honda et al. (2005). Global cooling initiated stony deserts in central Australia 2-4 Ma dated by cosmogenic 21Ne-10Be. Geology 33: 993-996.
Gallagher, S. J. and T. L. Gourley (2007). Revised Oligo-Miocene stratigraphy of the Murray Basin, southeast Australia. Australian Journal of Earth Sciences 54: 837-849.

Gallagher, S. J. and G. Holdgate (2000). The palaeogeographic and palaeoenvironmental evolution of a Palaeogene mixed carbonate-siliciclastic cool-water succession in the Otway Basin, Southeast Australia. Palaeogeography, Palaeoclimatology, Palaeoecology 156: 19-50.

Gallagher, S. J., D. R. Greenwood, D. Taylor et al. (2003). The Pliocene climatic and environmental evolution of southeastern Australia: evidence from the marine and terrestrial realm. Palaeogeography, Palaeoclimatology, Palaeoecology 193: 349-382.

Gallagher, S. J., A. J. Smith, K. Jonasson et al. (2001). The Miocene palaeoenvironmental and palaeoceanographic evolution of the Gippsland Basin, Southeast Australia: a record of Southem Ocean change. Palaeogeography, Palaeoclimatology, Palaeoecology 172: 53-80.

Gallagher, S. J., B. E. Wagstaff, J. Baird, M. W. Wallace and C. L. Li (2008). Climate variability in the Late Cretaceous greenhouse world Global and Planetary Change 60: 351-364.

Gallagher, S. J., M. W. Wallace, C. L. Li et al. (2009). Neogene history of the West Pacific Warm Pool, Kuroshio and Leeuwin currents. Palaeoceanography 24: doi:10.1029/ 2008PA001660.

Gillett N. P., T. D. Kell and P. D. Jones (2006). Regional climate impacts of the Southern Annular Mode. Geophysical Research Letters 33: L23704, doi:10.1029/2006GL027721.

Gradstein, F. M., J. G. Ogg and A. G. Smith (2004). A Geologic Time Scale. Cambridge: Cambridge University Press.

Gregory, R. T., C. B. Douthitt, I. R. Duddy, P. V. Rich and T. H. Rich (1989). Oxygen isotopic composition of carbonate concretions from the lower Cretaceous of Victoria, Australia: implications for the evolution of meteoric waters on the Australian continent in a paleopolar environment. Earth and Planetary Science Letters 92: 27-42.

Groves, R. H. (1999). Present vegetation types. In A. E. Orchard (ed.), Flora of Australia, Vol. 1. Melbourne, Australia: ABRS/CSIRO, pp. 369-401.

Hartley, A. J. and G. Chong (2002). Late Pliocene age for the Atacama Desert: Implications for the desertification of western South America. Geology 30: 43-46.

Hays, J. D. and W. C. Pitman (1973). Lithospheric plate motion, sea level changes and climatic and ecological consequences. Nature 246: 18-22.

Head, M. J. and P. L. Gibbard (2005). Early-middle Pleistocene transitions: an overview and recommendation for the defining boundary. Geological Society, London. Special Publication 247: 1-18.

Herczeg, A. L. and A. Chapman (1991). Uranium-series dating of lake and dune deposits in southeastern Australia: a reconnaissance. Palaeogeography, Palaeoclimatology, Palaeoecology 84: 285-298.

Hesse, P. P. (1994). The record of continental dust from Australia in Tasman sea sediments. Ouaternary Science Reviews 13: 257-272.

Hesse, P. P and G. H. McTainsh (2003). Australian dust deposits: modem processes and the Quaternary record Quaternary Science Reviews 22: 2007-2035.

Hesse, P. P., J. W. Magee and S. van der Kaars (2004). Late Quaternary environments of the Australian arid zone: a review. Quatemary International 118-119: 87-102.

Hill, R. S. ed., (1994). History of the Australian Vegetation: Cretaceous to Recent. Cambridge: Cambridge University Press.

Hoffman, P. F., A. J. Kaufinan, G. P. Halverson and D. P. Schrag, (1998). A Neoproterozoic snowball Earth. Science 281: 1342-1346. 
Holdgate, G. R., M. W. Wallace, S. J. Gallagher, B. E. Wagstaff and D. Moore (2008). No mountains to snow on: major post-Eocene uplift of the East Victoria Highlands; evidence from Cenozoic deposits. Australian Journal of Earth Sciences 55: 211-234.

Holdgate, G. R., B. McGowran, T. Fromhold et al. (2009). Eocene-Miocene carbon-isotope and fioral record from brown coal seams in the Gippsland Basin of southeast Australia. Global and Planetary Change 65: 89-103.

Howchin, W. (1929). Notes on the geology of the Great Pyap Bend (Loxton) River Murray basin, and remarks on the geological history of the River Murray. Transactions of Royal Society of South Australia 53: 167-195.

Huber, B. T. (1998). Palaeoclimate: Enhanced tropical paradise at the Cretaceous poles. Science 282(5397): 2199-2200.

Huber, B. T., D. A. Hodell and C. P. Hamilton (1995). Middle-late Cretaceous climates of the southem high latitudes: stable isotopic evidence from minimal equator-to-pole themnal gradients. Geological Society of America Bulletin 107.

Kemp E M (1978). Tertiary climatic evolution and vegetation history in the southeast Indian Ocean region. Palaeogeography, Palaeoclimatology, Palaeoecology 24: 169-208.

Kenley, P. R. (1971). Cenozoic geology of the eastern part of the Gambier Embayment, southwestern Victoria. In H. Wopfner and J. G. Douglas (eds), The Otway Basin of Southeastern Australia. Special Bulletin. Victoria, Australia: Geological Surveys of South Australia and Victoria, pp. 89-153.

Kershaw, A. P. (1997). A bioclimatic analysis of early to middle Miocene Brown Coal Floras, Latrobe Valley, south-eastem Australia. Australian Journal of Botany 45: 373-387.

Kershaw, A. P. and G. C. Nanson, (1993). The last full glacial cycle in the Australian region. Global and Planetary Change 7: 1-9.

Kershaw, A. P., D. M. D'Costa, J. R. C. McEwen Mason and B. E. Wagstaff (1991). Palynological evidence for Quaternary vegetation and environments of mainland southeastern Australia. Quaternary Science Reviews 10: 391-404

Kershaw, A. P., H. A. Martin and J. C. McEwen Mason (1994). The Neogene: a time of transition. In R. S. Hill (ed), History of the Australian Vegetation: Cretaceous to Recent. Cambridge: Cambridge University Press, pp. 299-327.

Kershaw, A. P., P. Moss and S. van der Kaars (2003). Causes and consequences of long-term climatic variability on the Australian continent. Freshwater Biology 48: 1274-1283.

Kidson, J W. (1988). Indices of the soutbern hemisphere zonal wind. Journal of Climate 1: 183194.

Kulhmann, G., C. Langereis, D. Munsterman et al. (2006). Chronostratigraphy of Late Neogene sediments in the southem North Sea Basin and palaeoenvironmental interpretations. Palaeogeography, Palaeoclimatology, Palaeoecology 239: 426-455.

Lear, C. J., Elderfield, H. and Wilson, P. A. (2000). Cenozoic deep-sea temperatures and global ice volumes from $\mathrm{Mg} / \mathrm{Ca}$ in benthic foraminiferal calcite. Science 287: 269-272.

Li, Z. X. and C. McA. Powell (2001). An outline of the palaeogeographic evolution of the Australasian region since the beginning of the Neoproterozoic. Earth Science Reviews 53: 237-277.

Li Q. Y., P. G. Quilty, G. Moss and B. McGowran (1996). Southem Australian endemic and semiendemic foraminiferd: a preliminary report. Journal of Micropalaeontology 15: 169-186.

(2005). A Pliocene-Pleistocene stack of 57 globally distributed ben, $1 \delta^{18}$ records Paleoceonography 20: PA1003, doi:10.1029/2004PA001071.

Lyle, M., J. A. Barron, T. J. Bralower et al. (2008). Pacific ocean and Cenozoic evolution of climate. Review of Geophysics 46: 1-47.
MacLeod, K. G., B. T. Huber, T., Pletsch and U. Röhl (2001). Maastrichtian foraminiferal and paleoceanographic changes on Milankovitch timescales. Paleoceanography 16: 133-154.

Macphail, M. K. (1997). Late Neogene climates in Australia: fossil pollen- and spore-based estimates in retrospect and prospect. Australian Journal of Botany 45: 425-464.

Macphail, M. K., N. F. Alley, E. M. Truswell and I. R. Sluiter (1994). Early Tertiary vegetation: evidence from spores and pollen. In R. S. Hill (ed.), History of the Australian Vegetation: Cretaceous to Recent. Cambridge: Cambridge University Press, pp. 188-261.

McBride, J. L. and N. Nicholls (1983). Seasonal relationships between Australian rainfall and the Southern Oscillation. Monthly Weather Review 111: 1998-2003.

McEwen Mason, J. R. C. (1991). The late Cenozoic magnetostratigraphy and preliminary palynology of Lake George, New South Wales. In M. A. J. Williams, P. De Deckker an A. P. Kershaw (eds), The Cainozoic in Australia: A Re-appraisal of the Evidence. Melboume, Australia: Geological Society of Australia, pp. 195-209.

McLaren, S. and M. W. Wallace (2010). Plio-Pleistocene climate change and the onset of aridity in southeastem Australia. Global and Planetary Change 71: 55-72.

McLaren, S., M. W. Wallace, B. Pillans et al. (2009). Revised stratigraphy of the Blanchetown Clay, Murray Basin: age constraints on the evolution of megalake Bungunnia Australian Journal of Earth Sciences 56: 595-604.

McLaren, S., M. W. Wallace and T. Reynolds (2012). Late Pleistocene climatic change and the formation of the modern Murray River, southeastem Australia. Palaeogeography, Palaeoclimatology, Palaeoecology 317-318: 114-127.

Martin, H. A. (1978). Evolution of the Australian flora and vegetation through the Tertiary: evidence from pollen. Alcheringa 2: 181-202.

Martin, H. A. (1989). Evolution of Mallee and its environment. In: J. C. Noble and R. A. Bradstock (eds), Mediterranean Landscapes in Australia. Melbourne, Australia: CSIRO, pp. 83-92.

Martin, H. A. (1990). The palynology of the Namba Formation in the Wooltana-1 bore, Callabonna Basin (Lake Frome), South Australia, and its relevance to Miocene grasslands in central Australia. Alcheringa 14: 247-255.

Martin, H. A. (1993). The palaeovegetation of the Murray Basin, late Eocene to mid Miocene. Australian Systematic Botany 6: 491-531.

Martin H. A. (1994). Australian Tertiary phytogeography: evidence from pollen. In R. S. Hill (ed.), History of the Australian Yegetation: Cretaceous to Recent. Cambridge: Cambridge University Press, pp. 104-142

Martin, H. A. (2006). Cenozoic climatic change and the development of the arid vegetation in Australia. Journal of Arid Environments 66: 533-563.

Martin, H. A. and A. McMinn (1994). Late Cenozoic vegetation history of north-western Australia from the palynology of a dee sea core (ODP Site 765). Australian Journal of Botany 42: 95-102.

Megirian, D. (1992). Interpretation of the Carl Creek Limestone, northwestern Queensland. Records of the Northern Territory Museum of Arts and Sciences 9: 219-248.

Meloro, C., P. Raia and F. Carotenuto (2008). Diversity and turnover of Plio-Pleistocene large mammal fauma from the Italian Peninsula Palaeogeography, Palaeoclimatology, Palaeoecology 268: 58-64.

Miller, K. G., M. A. Kominz J. V. Browning et al. (2005). The Phanerozoic record of global sealevel change. Science 310: 1293-1298.

Miller, K. G., P. J. Sugarman, J. V. Browning et al. (2003). Late Cretaceous chronology of large, rapid sea-level changes: glacioeustasy during a greenhouse world. Geology 31: 585-588. 
Miller, K. G., P. J. Sugannan, J. V. Browning et al. (2004). Upper Cretaceous sequences and sealevel history, New Jersey Coastal Plain. Geological Society of America Bulletin 116: 368-392.

Moss, G. and B. McGowran, (2003). Oligocene neritic Foraminifera in southern Australia; spatiotemporal biotic patterns reflect sequence-stratigraphic environmental patterns, Special Publication-Society for Sedimentary Geology 75: 173-199.

Nanson, G. C., D. M. Price and S. A. Short (1992). Wetting and drying of Australia over the past 300 ka. Geology 20: 791-794.

Palombo, M. R., M. T. Alberdi and B. Azanza (2009). How did environmental disturbances affect carnivoran diversity? A case study of the Plio-Pleistocene Camivora of the North-Westem Mediterranean. Evolutionary Ecology 23: 569-589.

Pole, M. S., R. S. Hill, N. Green and M. K. Macphail (1993). The Oligocene Berwick Quarry flora: rainforest in a drying environment. Australian Systematic Botany 6: 399-427.

Pye, K. (1987). Aeolian Dust and Dust Deposits. San Diego, CA: Academic Press.

Quilty, P. G. (1994). The background: 144 million years of Australian palaeoclimate and palaeogeography. In R. S. Hill (ed.), History of the Australian Vegetation: Cretaceous to Recen Cambridge: Cambridge University Press, pp. 14-43

Raymo, M. E., L. E. Lisiecki and K. H. Nisancioglu (2006). Plio-Pleistocene ice volume, Antarctic climate, and the global ?180 record. Science 313: 492-495.

Reed, K. E. (1997). Early hominid evolution and ecological change through the African PlioPleistocene. Joumal of Human Evolution 32: 289-322.

Rich, P. V., T. H. Rich, B. E. Wagstaff et al. (1988). Evidence for low temperatures and biologic diversity in Cretaceous high latitudes of Australia. Science 242: 1403-1406.

Ruddiman, W. F. and J. E. Kutzbach (1989). Forcing of Late Cenozoic northem hemisphere climate by plateau uplift in Southem Asia and the American West. Journal of Geophysical Research 94: 18 409-18 427.

Sluiter I. R. K. (1991). Earth Tertiary vegetation and climates, Lake Eyre region, northeastem South Australia In M. A. J. Williams, P. De Deckker and A. P. Kershaw (eds), The Cenozoic in Australia: A Re-appraisal of the Evidence. Melboume, Australia: Geological Society of Australia, pp. 99-166.

Smith, M. L., B. J. Pillans and K. G. McQueen (2009). Paleomagnetic evidence for periods of intense oxidative weathering, McKinnons mine, Cobar, New South Wales. Australian Journal of Earth Sciences 56: 201-212.

Snidernan, J. M. K., B. Pillans, P. B. O'Sullivan and A. P. Kershaw (2007). Climate and vegetation in southeastern Australia respond to southem hemisphere insolation forcing in the late Plioceneearly Pleistocene. Geology 35: 41-44.

Specht, R. L. and A. Specht (2002). Australian Plant Communities: Dynamics of Structure, Growth and Biodiversity, 2nd edn. Oxford: Oxford University Press.

Stanley, S. M. (1992). An ecological theory for the origin of Homo. Palaeobiology 18, 237-257. Stephenson, A. E. (1986). Lake Bungunnia - A Plio-Pleistocene megalake in southem Australia. Palaeogeography, Palaeoclimatology, Palaeoecology 57: 137-156.

Stickley, C. E. H Brinkhuis, S. A. Schellenberg et al. (2004). Timing and nature of the deepening of the Tasmanian Gateway, Paleaceanography, 19, PA4027, doi:10.1029/2004PA001022.

Travouillon K. J., S. Legendreb, M. Archera and S. J. Hand (2009). Palaeoecological analyses of Riversleigh's Oligo-Miocene sites: Implications for Oligo-Miocene climate change in Australia. Palaeogeography, Palaeoclimatology, Palaeoecology, 276: 24-37.
Truswell, E. M. and W. K. Harris (1982). The Cenozoic palaeobotanical record in arid Australia: fossil evidence for the origins of an arid-adapted flora. In W. R. Barker and P. J. M. Greenslade (eds), Evolution of the Flora and Fauna of Arid Australia. Adelaide, Australia: Peacock Publications, pp. 67-76.

Vizcaino S. F., R. A. Farina, M. A. Zarate, M. S. Bargo and P. Schultz (2004). Palaeoecological implications of the mid-Pliocene faunal turnover in the Pampean Region (Argentina). Palaeogeography, Palaeoclimatology, Palaeoecology 213: 101-113.

Wagstaff, B. E., A. P. Kershaw, P. B. O'Sullivan, K. J. Harle and J. Edwards (2001). An Early to Middle Pleistocene palynological record from the volcanic crater of Pejark Marsh, Western Plains of Victoria, southeastern Australia. Quaternary International 83-85: 211-232.

Webb J. A. and S. A. Golding (1998). Geochemical mass-balance and oxygen-isotope constraints on silcrete formation and its paleoclimatic implications in Southern Australia. Journal of Sedimentary Research 68: 981-993.

Weissert, H. and E. Erba (2004). Volcanism, $\mathrm{CO}_{2}$ and palaeoclimate: a late Jurassic-Early Cretaceous carbon and oxygen record. Journal of the Geological Society 161: 695-702.

White, S. and M. M. Mitchell (2000). Palaeoclimates, the influence of continental drift and latitude change on climate In W. D Birch (ed) The Geology of Victoria. Sydney, Australia: Geological Society of Australia Special Publication 23, pp. 563-572.

Williams, A. A. J. and R. C. Stone (2009). An assessment of relationships between the Australian subtropical ridge, rainfall variability, and high-latitude circulation patterns. International Journal of Climatology 29: 691-709.

Wolfe, J. A. and G. R. Upchurch (1986). Vegetation climate and floral changes at the CretaceoursTertiary boundary. Nature 324: 148-152.

Wynn, J. G. (2004). Influence of Plio-Pleistocene aridification on human evolution: Evidence from paleosols of the Turkana Basin, Kenya. American Journal of Physical Anthropology 123 106-118.

Zachos, J., G. R. Dickens and R. E. Zeebe (2008). An early Cenozoic perspective on greenhouse warming and carbon-cycle dynamics. Nature 451: 279-283.

Zachos, J., M. Pagani, L. Sloan, E. Thomas and K. Billups (2001). Trends, rhythms and aberrations in global climate 65 Ma to present. Science 292: 686-693.

Zheng, H., K-H. Wyrwoll, Z. Li and C. McA. Powell (1998). Onset of aridity in southern Western Australia: a preliminary palaeomagnetic appraisal. Global and Planetary Change 18: 175-187. 